\title{
BUSINESS FINANCIAL MANAGEMENT EDUCATION DURING THE COVID-19 PANDEMIC FOR PASAR RAYA STREET VENDORS IN SALATIGA
}

\author{
Ani Siska MY*, Ekayana Sangkasari PARANITA \\ Faculty of Economics and Business, Sahid University, Indonesia \\ *anisiskamy961989@gmail.com
}

\begin{abstract}
This community development activity aims to provide education on business financial management to street vendors at Pasar Raya in Salatiga City. During the Covid-19 pandemic, the government implemented regulation on Community Activity Restrictions, which resulted in the Pasar Raya being empty of visitors, resulting in a drastic drop in sales for street vendors. Most street vendors do not understand business financial management and have a debt to meet their primary needs. Education is carried out by identifying problems, formulating approach methods, planning work procedures, and conducting business financial management education. In addition, it is also directed to avoid debt on online loans that do not have official permission and get used to saving. After this education is carried out, street vendors better understand business financial management, will no longer be in debt on online loans that do not have official permits, try to save money to become bankable business actors for business continuity in the future.
\end{abstract}

Keywords: financial management, income, and expenses statement, saving.

\section{BACKGROUND}

Salatiga City is located in the heart of Central Java Province, on the main route of the Trans Java Toll Road that connects Semarang City, Boyolali Regency, and Surakarta City, as shown in Figure 1. This city has cool air because it is surrounded by Mount Merbabu, Sindoro, and Sumbing. The beauty of this city has been recognized since the Dutch East Indies colonial period, earning the nickname De Schoonste Stad van Midderi-Java or the most beautiful city in Central Java. The city of Salatiga has an area of \pm 54.98 square kilometers and a population of 196,082 people (BPS, 2020).

The majority of the residents of Salatiga City work in the trade sector, especially from 15 traditional markets. In line with the rapid development of the market in Salatiga, the presence of street vendors is also overgrowing. Street vendors are people who transact on roads or sidewalks, which should be the rights of pedestrians. Street vendors are a reflection of the resilience of the people who struggle to maintain their household economy. The presence of street vendors is a dilemmatic condition. On the one hand, the community's presence of street vendors is awaited because they provide daily needs at economical prices in strategic locations. But on the other hand, the presence of street vendors can add to the complexity of the market and even disrupt traffic lanes.

The number of street vendors in Salatiga City in the last four years has increased significantly. In 2020, the number of street vendors was 594 traders spread over 38 locations. The market with the highest number of street vendors is Pasar Raya, with 54 street vendors. This is because Pasar Raya is located on the protocol road, namely Jalan Jenderal Sudirman, the center of Salatiga City. Pasar Raya is the primary market in the city of Salatiga, which operates 24 hours a day.

The Covid-19 pandemic that has spread in Indonesia since March 2020 and continues to this day impacts the decline in economic growth in all sectors (Ashraf, 2020; Hardiwardoyo, 2020; Nasution et al., 2020).
The government has issued regulations to decrease the Covid-19 cases by prohibiting crowds, schools conducting online learning, and limiting office and market operating hours. This regulation is like a double-edged sword because it tends to reduce the spread of the Covid-19 virus but causes all public spaces to be quiet so that the economy slows down.

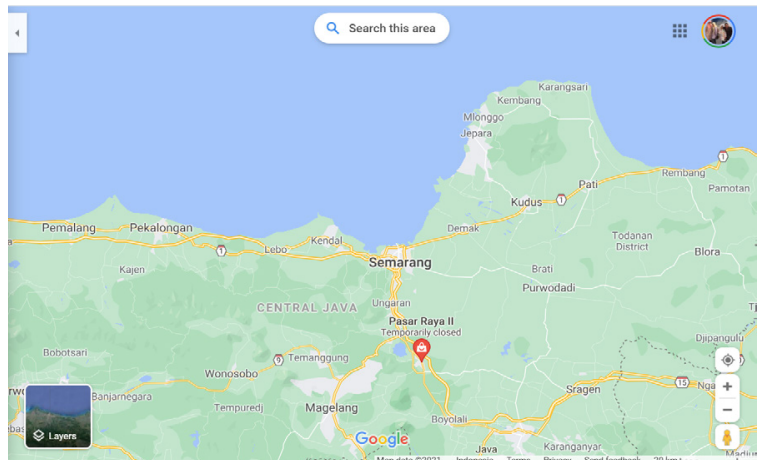

Figure 1. Map of Salatiga City

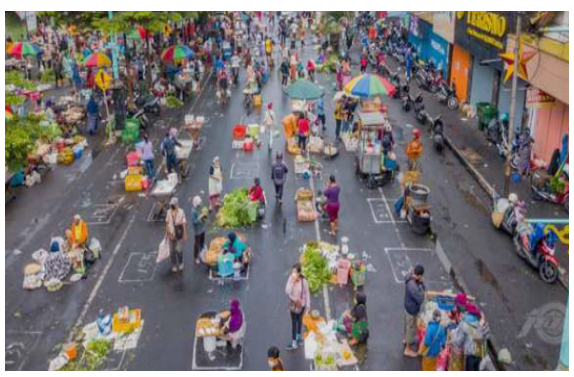

Figure 2. Physical Distancing Market

The restrictions on community activities have declined; the market is only open with limited operating hours. On Sunday, the Salatiga City Government set two meters between traders' stalls at Pasar Raya as the largest market in Salatiga. The arrangement extends to the highway. Photos of Pasar Raya Salatiga that apply social distancing, as shown in Figure 2, have gone viral on social media. Meanwhile, on other days, the market tends to be quiet because most people stay at home. The situation of Pasar Raya, which keeps its distance on this Sunday, has shifted the land which was originally an area for street 
vendors, while on other days there are very few visitors. This phenomenon causes the income of street vendors to decrease drastically. This causes their economic resilience to weaken. Weak economic conditions make it difficult for street vendors to meet their primary needs and seek loans to meet their needs.

In general, street vendors do not understand the financial management of their business. They do not have an income and expenses statement related to their business. Even if someone records it, the cash flow has not been well organized so that sometimes the nominal recorded is not the same as the little cash he holds. In addition, they also do not recognize reliable sources of financing and do not understand the allocation of savings or investments from the sales proceeds.

The common understanding of the financial management of the street vendor business is very concerning. This is in line with the condition of the majority of micro business actors that they tend not to understand the concept of managing their business financial management (Jumhur, 2015; Anggraeni, 2016; Sudana et al., 2017; Suryani \& Ramadhan, 2017; Hafifah, 2019; Paranita, 2020). This has prompted the holding of some training, mentoring, and community service programs.

Community service programs that assist SMEs in East Java conclude that financial literacy can pose a danger of being entangled in moneylenders (Amalia \& Rahmawati, 2019). A study on SMEs in West Java stated that financial literacy had a significant effect on business growth (Sabilla \& Wijayaka, 2019). Financial literacy analysis on SMEs in Medan states that financial literacy is necessary for businesses and survival in a competitive climate (Panggabean et al., 2018). Studies on MSMEs in East Java state that financial literacy is a significant factor that plays a role in MSME performance (Pramestiningrum \& Irani, 2020; Rahayu \& Musdholifah, 2017).

Street vendors are rife around campuses in Bandung City, but their existence tends to decline, so business financial management training is held (Amaranti et al., 2018). Assistance training in family financial management as the cornerstone of community finance in the Semarang City is carried out to reduce consumerism and increase understanding of simple financial management knowledge (Sukirman et al., 2019). Research on the empowerment of micro, small and medium enterprises in West Java and East Java Provinces concludes that capital, skill, and technological constraints make micro, small, and medium enterprises uncompetitive (Maksum et al., 2020). Community development programs that provide education to micro-enterprises in Central Java and the Special Region of Yogyakarta Province conclude that, in general, the financial understanding of micro-enterprises is shallow, so education is needed to improve knowledge and skills of business financial management (Hirawati et al., 2021).

The condition of the low financial literacy of street vendors in Salatiga City can be exploited by a handful of parties who offer financing shortcuts with high costs and lucrative investments. If concrete steps are not taken immediately, it is feared that street vendors will experience mismanagement in their financial management and will be tempted by irresponsible investments. Therefore, it is urgent to carry out community service programs in financial management education and improving financial literacy.

Based on this background, it is urgent to organize business financial management education for street vendors at Pasar Raya in Salatiga City. The program was held in May 2021, after the Restrictions on Community Activities published by the Central Java Provincial Government.

Financial management is an action to achieve financial goals in the future, which includes personal financial management, family financial management, and company financial management. Financial management is an essential part of overcoming economic problems, both individual, family, and company economic problems (Sukirman et al., 2019). The objectives of financial management include achieving specific fund targets in the future, protecting and increasing wealth, managing cash flow, managing accounts payable, and managing risk.

Business financial management activities are the key to smooth business operations. The use of funds that are not controlled will result in disruption of cash flow. Liquid cash flow management shows credibility in the business world (Layyinaturrobaniyah \& Muizu, 2017). Business financial management in Micro, Small, and Medium Enterprises includes several essential processes to be carried out. In general, business financial management must go through the stages of planning, budgeting, and financial control (Rumbianingrum \& Wijayangka, 2018).

Financial management steps include assets, income, and expenses statements, identifying daily monthlyannual expenses, preparing expenditure plans, and saving periodically (Sukirman et al., 2019). The statement of assets aims to identify productive assets and non-productive assets. Income and expenses statement is significant to control unnecessary expenses and control the frequency of significant expenses. The process of identifying dailymonthly-annual expenditures will make it easier to develop a priority scale for meeting needs. The preparation of an expenditure plan is crucial because it determines the future financial management pattern. Periodic saving is not only a complement to financial management but also a safety bulwark.

\section{METHODS}

Implementing Community Development activities for education on business financial management for street vendors at Pasar Raya in Salatiga City is carried out by identifying problems, formulating approach methods, planning work procedures, and conducting business financial management education. Identifying the problems studied 
during the pre-survey to the street vendor association at Pasar Raya in Salatiga City was the common understanding of business finance and assistance in implementing simple financial management.

Based on the identification of the problems that have been raised, in this activity, the approach method used is to visit the stalls of street vendors at Pasar Raya in Salatiga City and hold education while having lunch together in a family atmosphere. To achieve the expected goals, the work procedures carried out to realize them are by listening to the problems from the side of street vendors. The presenters explain business financial management and continue with discussions. This methodology is in line with educational activities in the Micro, Small, and Medium Enterprises sector carried out in several cities on the island of Java (Amaranti et al., 2018; Sukirman et al., 2019; Maksum et al., 2020; Hirawati et al., 2021).

The participation of street vendors at Pasar Raya Salatiga City includes presenting financial phenomena and problems faced related to the implementation of Restrictions on Community Activities during the Covid-19 pandemic and participating in education about financial management street vendors. Visits to stalls at Pasar Raya in Salatiga City were held in four days; education was held at the house of the head of the street vendor association at Pasar Raya in Salatiga City in three hours, then in the following month monitoring of the implementation of business financial management was carried out.

\section{RESULT AND DISCUSSION}

The preparation stage includes identifying problems, formulating approach methods, and planning work procedures. This stage begins with studying the regulations for Restricting Community Activities in Salatiga City, where street vendors are limited to shorter operating hours. Meanwhile, people are encouraged to stay at home, so the market is quiet, and street vendors have drastically reduced their income. Then meet with the head of the street vendor association to describe the purpose of the activity and confirm the schedule of activities. She is very responsive and supports activities by coordinating street vendors with educational participants, helping to take care of licensing educational activities, even allowing her house as a place to conduct business financial management education.

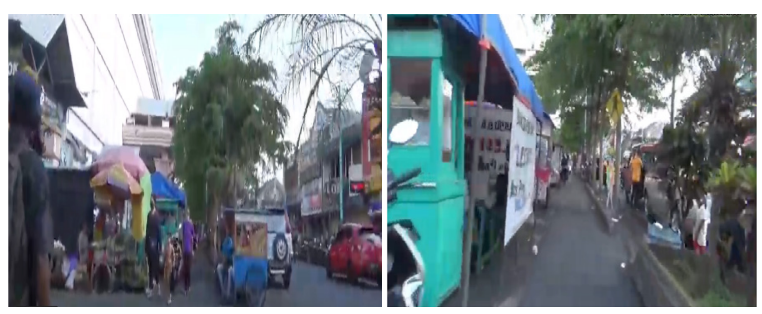

Figure 3-4. Street Vendors at Pasar Raya

Based on identifying these problems, an adequate approach was formulated by visiting street vendors' stalls at Pasar Raya in Salatiga City. At this stage, it is observed that Pasar Raya is quiet, the number of visitors is minimal, and the number of street vendors selling is minimal. In addition to a visit to Pasar Raya, it was also deemed necessary to gather members of the street vendor association in a family-friendly meeting to discuss financial management education. For this reason, the next step is the preparation of educational concepts, the manufacture of educational modules, and the preparation of the presenter.

Implementing education as the core activity is packaged in casual meetings, starting with lunch together. The meeting was attended by 35 people, according to the maximum number of people allowed to attend the meeting in conditions of the Covid-19 pandemic. To achieve the expected goals, the team listened to the problems from the side of street vendors. The presenters explained the financial management of the business and continued with discussions. The training participants are street vendors who are not highly educated; therefore, the delivery of the material is designed in a non-formal manner. The educational material is intended to equip street vendors with the knowledge to manage their business with feasible management.

During the listening session on the problems of the street vendors, information was obtained that they had not had their assets statement. In this regard, they are directed to record the ownership of the carts, tables, chairs, kitchen utensils, and eating utensils as assets, debts, or rent. They also have not recorded their income and expenses, so the presenter educated each street vendor to record all their income and expenses every day and separate expenses for business from expenses for family needs. The presenter also educated street vendors to identify daily-monthlyannual expenses to plan rent payments, purchase kitchen utensils, and to eat utensils in a more organized manner. Furthermore, street vendors understand the importance of preparing an expenditure plan to manage their expenses according to a priority scale. Then no less critical is an understanding of the benefits of the habit of saving periodically. It should be in the habit of setting aside income for savings when you receive it because if you save while waiting for the remaining funds, savings will never be collected. During a pandemic and sales slump, savings are precious.

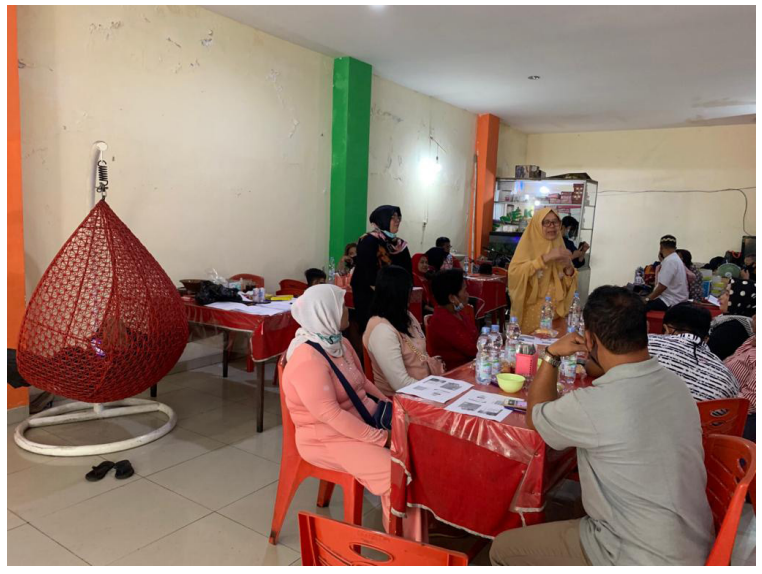

Figure 7. Presentation \& Discussion 


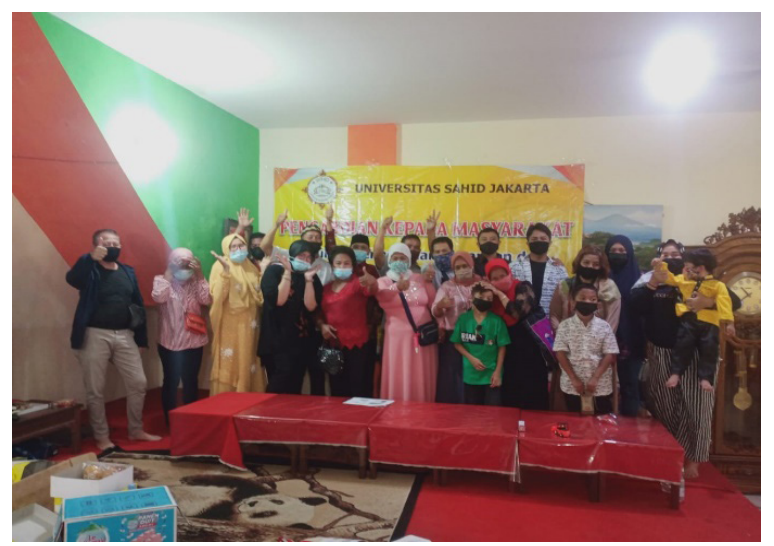

Figure 8. Street Vendors at Our Meeting

The discussion stage became an exciting session because there was an interactive dialogue between the presenter and street vendors. The silence of Pasar Raya and the decline in income are the complaints of all street vendors, so most of them have debts to cover their primary needs. Presenters provide education, so street vendors do not apply for debt on online loans because they charge very high-interest rates. It is feared that they will be in debt on online loans that swell, and eventually, their assets will be confiscated. In urgent conditions, they are directed to pay debts only to official financial institutions registered with the Financial Services Authority, such as Koperasi Simpan Pinjam, Bank Pasar, or Bank Perkreditan Rakyat. At the end of the event, the presenter motivated the street vendors to be enthusiastic about implementing business financial management and possible, hoping that they will become bankable businessmen because they have a simple operational financial statement. In addition, suggestions are given for street vendors to offer their food through social media.

\section{CONCLUSION}

The Covid-19 pandemic impacts all business sectors, especially the Micro, Small, and Medium Enterprises sectors. To decrease the spread of the Covid-19 virus, the government has implemented a Community Activity Restriction regulation that limits the operating hours of offices, schools, and trade centers and urges people to stay at home. This also has an impact on Pasar Raya as the largest market in Salatiga City. Pasar Raya became empty of visitors, so that street vendors dropped their sales drastically. The majority of these street vendors do not understand business financial management, and they have a debt to meet their primary needs. This condition is vulnerable to falling into debt from unofficial online loans, which are stifling with very high-interest rates. The team conducted education on business financial management by visiting the stalls of street vendors in Pasar Raya and holding meetings to listen to their problems, provide an understanding of business financial management, and discuss. Education is carried out by identifying problems, formulating approach methods, planning work procedures, and conducting business financial management education.
In addition, it is also directed to avoid debt on online loans that do not have official permission and get used to saving. Street vendors receive the education program; they hope to implement it to become businessmen qualified to manage business finances and are bankable for business continuity in the future.

\section{ACKNOWLEDGEMENT}

The Batch X Community Development Grant funds this community development program for the Fiscal Year 2020/2021 from Sahid University. The authors are very grateful to the Office for Research and Community Development in Sahid University, which facilitated the implementation of this program and the proposal review process. The author also greatly appreciates Mrs. Yarti as the Chair of the Salatiga Street Street Vendors Association, who provides full support for implementing this activity.

\section{REFERENCES}

Amalia, A. F., \& Rahmawati, L. (2019). Pendampingan Manajemen Keuangan Melalui Program Literasi Keuangan Kepada Komunitas Usaha Mikro Kecil dan Menengah (UMKM) yang Terjerat Rentenir di Kabupaten Nganjuk. Engagement: Jurnal Pengabdian Kepada Masyarakat, 3(1), 113-126.

Amaranti, R., Nugraha, Arif, A.N., \& Dzikron, M. (2018). Peningkatan Kemampuan Manajemen Wirausaha untuk Pedagang Kaki Lima di Lingkungan Kampus Unisba. Jurnal Penelitian dan Pengabdian Masyarakat, 6(1), 146-152.

Anggraeni. (2016). Pengaruh Tingkat Literasi Keuangan Pemilik Usaha terhadap Pengelolaan Keuangan: Studi Kasus UMKM Depok. Jurnal Vokasi Indonesia, 4(1), 43-50.

Ashraf, B.N. (2020). Economic Impact of Government Interventions during the Covid-19 Pandemic: International Evidence from Financial Markets. Journal of Behavioral Finance, 27, 1-9.

BPS. (2020). Kota Salatiga Dalam Angka.

Hafifah, A. (2019). Literasi Keuangan Pada Pelaku Usaha Mikro Kecil dan Menengah di Kecamatan Ambulu Kabupaten Jember. Prosiding Seminar Nasional dan Call for Paper-2019, 259-271.

Hardiwardoyo, W. (2020). Kerugian Ekonomi Nasional Akibat Pandemi Covid-19. Journal of Business \& Enterpreneurhip. 2(2), 83-92.

Hirawati, H., Sijabat, Y.P. \& Giovanni, A. (2021). Literasi Keuangan, Toleransi Risiko, dan Pengelolaan Keuangan Pelaku Usaha Mikro. Society. 9(1). 184196.

Jumhur. (2015). Model Pengembangan Pedagang Kaki Lima (PKL) Kuliner di Kota Singkawang. Jurnal Ekonomi Bisnis Dan Kewirausahaan, 4(1), 125-139. 
Maksum, I. R., Rahayu, A.Y. \& Kusumawardhani, D. (2020). A Social Enterprise Approach to Empowering Micro, Small and Medium Enterprises (SMEs) in Indonesia. Journal of Open Innovation: Technology, Market and Complexity, 6, 1-17.

Nasution, D.A.D., Erlina., \& Muda. I. (2020). Dampak Pandemi Covid-19 terhadap Perekonomian Indonesia. Jurnal Benefita, 5(2), 212-224.

Layyinaturrobaniyah., \& Muizu, W.O.Z. (2017). Pendampingan Pengelolaan Keuangan Usaha Mikro di Desa Purwodadi Barat dan Pasir Bungur Kabupaten Subang. Jurnal Pekbis. 9(2). 91-103.

Panggabean, F. Y., Dalimunthe, M. B., Aprinawati, A., \& Napitupulu, B. (2018). Analisis Literasi Keuangan terhadap Keberlangsungan Usaha Kuliner Kota Medan. Jurnal Manajemen Dan Keuangan, 7(2), 139-147.

Paranita, E. S. \& Harahap, A. S. (2020). Peningkatan Literasi Keuangan di Kampung Makan Rafels Jakarta Barat. International Journal of Communnity Service Learning, 4(3), 229-238.

Pramestiningrum, D. R., \& Iramani, I. (2020). Pengaruh Literasi Keuangan, Financial Capital, Kebijakan Pemerintah terhadap Kinerja Usaha pada Usaha Kecil dan Menengah di Jawa Timur. Journal of Business and Banking, 9(2), 279.
Rahayu, A. Y., \& Musdholifah. (2017). Pengaruh Literasi Keuangan terhadap Kinerja dan Keberlanjutan UMKM di Kota Surabaya. Jurnal Ilmu Manajemen, 5(3), 1-7.

Rumbianingrum, W. \& Wijayangka, C. (2018). Pengaruh Literasi Keuangan terhadap Pengelolaan Keuangan pada UMKM. Jurnal Manajemen dan Bisnis. 2(3). 155-164.

Sabilla, S. O., \& Wijayangka, C. (2019). Pengaruh Literasi Keuangan terhadap Pertumbuhan Usaha pada UMKM. Almana : Jurnal Manajemen Dan Bisnis, 3(1), 145-152.

Sudana, M., Putra, I. G. S. A., \& Nyoman, P. (2017). Pemberdayaan Masyarakat Desa dengan Usaha Kuliner Tradisional pada Kelompok Boga Ganesha Kabupaten Buleleng. Jurnal Agribisnis Dan Agrowisata, 6(3), 387-396.

Sukirman., Hidayah, R., Suryandari, D. \& Purwati, A. (2019). Pengelolaan Keuangan Keluarga dalam Rangka Peningkatan Masyarakat Mandiri dan Berperan dalam Peningkatan Literasi Keuangan Indonesia. Abdimas: Jurnal Pengabdian kepada Masyarakat, 23(2), 165-169.

Suryani, S., \& Ramadhan, S. (2017). Analisis Literasi Keuangan pada Pelaku Usaha Mikro di Kota Pekanbaru. Journal of Economic, Business and Accounting, 4(1), 9-15. 